\title{
Law as the Continuation of God by Other Means
}

\author{
Pierre Schlag $\dagger$
}

Even if one ascribes the rise of an orientation to its usefulness, one cannot conclude that it necessarily serves the ends of use. It may survive from conditions for which it was fit into conditions for which it is unfit (cultural lag).... The members of a group specifically charged with upholding a given orientation may be said to perform a priesthood function.... The function is mainly performed by our college professors, journalists, public relations counselors ... many of whom will usually fume at the hypocrisy of the medieval Church while excusing their own position on the grounds of necessity. ${ }^{1}$

This essay explores a certain form of reasoning very popular in American jurisprudence. This is the kind of reasoning through which the legal thinker attempts to establish the existence of something fervently desired. ${ }^{2}$ This something could be any of a number of things: the rule of law, objectivity in interpretation, the autonomy of the individual self, progressive legal change-just about anything. What is essential about this thing-and I will call it a desirable X for short-is that its existence is indeed profoundly desired.

Typically, legal thinkers respond to such desires in a professional manner. That is to say, they respond by doing what they are good atnamely, constructing arguments. Specifically, they construct arguments to secure the existence of their own particular desirable $\mathrm{X}$.

It is the formal structure of these legal arguments that is in question here. My claim is that these legal arguments bear an uncanny and disturbing similarity to various proofs of God. Specifically, they resemble the cosmological proof, the argument from design, and the ontological

\footnotetext{
Copyright (C) 1997 California Law Review, Inc.

$\dagger \quad$ Nicholas Rosenbaum Professor, University of Colorado SchooI of Law. My thanks to Eric Blumenson and Steven Smith, who pointed me in the right directions. A version of this essay was presented at the AALS jurisprudence workshop in Los Angeles, October 13, 1995.

1. Kenneth Burke, Permanence and Change 179 (2d rev. ed. 1954) (emphasis omitted).

2.. See, e.g., STANLEy Fish, The Law Wishes to Have a Formal Existence, in There's No Such Thing as Free Speech and Ir's a Good Thing, Too 141 (I994) (arguing that the law wishes to "have a formal existence").
} 
proof. Thus, despite its secular pretensions, legal thought is in part a kind of theological activity. ${ }^{3}$ A more controversial and perhaps more surprising point is that, for those who believe in law, there is no alternative but to participate in this covertly theological discourse. For those legal academics who find this prospect unappealing, the alternative is clear: stop trying to "do law," or more accurately, stop pretending to "do law."

\section{The Cosmological Proof of God}

As an example of the jurisprudential use of the cosmological proof, consider the efforts of the great early-twentieth century formalist Joseph Beale to show that the decisions of common-law courts are guided by a common law that is always already changing, indeed, always already progressive.

Joseph Beale came to hold this view in the context of an argument designed to establish that judges do not make the law, but rather find it. ${ }^{4}$ This belief that judges find the law, as Beale himself noted, was very much threatened by "the prevailing fashion among thinking law. yers ... to assert that under gnise of discovering legal propositions the judges of common-law courts make the law which they purport to find."

Beale offered various reasons for rejecting this view. One argument took the form of showing that if judges did change the law, it would be a usurpation of sovereign authority. Therefore, argued Beale, judges do not change the law. But if that is true, then the question is why doesn't the common law remain always the same? Indeed, it might even be argued, "that unless the courts changed the law, the law must have been the same in 1200 that it is today." Here Beale makes a move every bit as clever as any piece of medieval scholasticism:

This line of reasoning, which has seemed convincing to many persons, is quite obviously a mere begging of the question. It is certain that the common law changes; not merely the common

3. And maintaining faith in this theology is an increasingly trying experience. See generally Paul F. Campos et al., Against the Law (1996); Pierre Schlag, Laying Down the Law: Mysticism, Fetishism, aNd the American Legal Mind (1996).

4. Compare Justice Scalia's wonderfully confused (or wonderfully sophisticated) formulation of the point:

I am not so naive (nor do I think our forebears were) as to be unaware that judges in a real sense "make" law. But they make it as judges make it, which is to say as though they were "finding" it-discerning what the law is, rather than decreeing what it is today changed to, or what it will tomorrow be.

James B. Beam Distilling Co. v. Georgia, 501 U.S. 529, 549 (1991) (Scalia, J., concurring) (emphasis omitted).

5. 1 Joseph H. Beale, A Treatise on the Conflict of Laws 38 (1935).

6. Id. at 39 . 
law of a particular jurisdiction, but the common-law system in general. This must be true, or the science of law, differing from all other sciences, would be unprogressive. The law of today must of course be better than that of seven centuries ago ....?

The argument, then, is that if law is a progressive science (which it is), and if the judges do not change the law themselves (which they don't), then the only way to avoid self-contradiction is to conclude (as indeed Beale does) that the common law is itself always already changing.

Not only is this an argument worthy of Stanley Fish, ${ }^{8}$ but it is indeed worthy of God himself. Specifically, it resembles what Immanuel Kant (among others) called the cosmological proof of God. ${ }^{9}$ In particular, Beale's logic has a certain affinity with the proof from motion advanced by Thomas Aquinas. Just as Joseph Beale observes that the common law seems to change, Thomas Aquinas takes note that "things are in motion in this world." How is this to be explained? According to Aquinas, if we are to avoid an untenable infinite regress, then "it is necessary to go back to some first mover who is not moved by anyone, and this everyone understands as God." 11

Beale makes an essentially similar move. In Beale's argument, the primal mover is the common law itself, which, as Beale argues, is itself always already changing, always already progressing. Indeed, to anticipate a later writer, it is always already well on its way to becoming the best it can be. ${ }^{12}$

Kant's thought points to what is objectionable with the cosmological proof. ${ }^{13}$ Two of his arguments deserve particular mention here. First, even if it is true that we can only explain a contingent fact of being (i.e., motion) on the basis of a non-contingent, necessary being (i.e., God), this would be true, if at all, only as a matter of logic or explanation. In other words, to say that we must base our explanation of contingent facts of being on the existence of a non-contingent, necessary being may reveal something about the nature of logic or explanation, but not being.

7. Id.

8. See generally Stanley Fish, Change, in Doing What Comes Naturally: Change, Rhetoric, aNd the Practice of Theory in Literary and Legal Studies 141, 150 (1989) (explaining that change occurs because the interpretive community is itself always already changing).

9. See Immanuel Kant, Critique of Pure Reason 507-18 (Norman Kemp Smith trans., St. Martin's Prcss unabr. ed. 1965) (1787).

10. Thomas Aquinas, The Summa of Theology, in St. Thomas Aquinas on Politics AND ErHics 30, 30 (Paul E. Sigmund ed. \& trans., 1988).

11. Id. at 31 .

12. See generally RoNald DwORKIN, LAW's EMPIRE (1986).

13. See KANT, supra note 9, at 507-18. 
The same is true of Beale's argument. It may be that for purposes of understanding a contingent aspect of law (e.g., its manifest change), one must posit that the law is necessarily a changing thing. But that reveals something only about the character of logic or explanation (the epistemic), not about the being of law itself (the ontological). In short, Beale's argument depends upon a slippage from the epistemic to the ontological.

A second problem with the cosmological proof is that even if one admits the necessary existence of a prime mover, there is no particular reason to describe this necessary being as God, as opposed to the devil or some impersonal force. The same, of course, holds for Beale's argument: there is no particular reason (other than wishful thinking) to presume that common law itself causes court-made law to change, as opposed to something less jurisprudentially appealing such as power, politics or rent-seeking. There is, in short, a crucial equivocation (and equation) between "the common law" as the name of the abstract selfmoving mover and "the common law" as the name of the more pedestrian body of case law. This equivocation is the same kind that allows Aquinas, after having asserted the existence of some necessary omnipotent being, to affirm at the end of his arguments: "And this being we call God"-meaning thereby the fully fleshed-out Judeo-Christian God.

Joseph Beale is generally not highly regarded among contemporary American legal thinkers. And so it may be thought that he is a poor representative of current American jurisprudence and that I have picked on a weak target. But there are more contemporary examples of the jurisprudential uses of the proofs of God. Consider as an example an argument by Owen Fiss-one that has a striking similarity to the proof of God known as the argument from design. ${ }^{14}$

\section{The Argument From Design}

Like Joseph Beale before him, Owen Fiss faced a challenge to his own desirable X. The challenge was "legal nihilism," and its target was "objectivity." Critical Legal Studies thinkers had argued that law was indeterminate, and objectivity illusory. What gave this critique its sting for many legal thinkers was that the source of constraint in legal interpretation remained vexingly unspecified. When asked how legal materials could constrain interpretation, legal thinkers were left with the intellectually embarrassing prospect of invoking rather mystical terms such as "binding authority" or "good judgment." But while the critique stung, it also remained, for most legal thinkers, quite unpersuasive.

14. Also called the teleological proof and, for Kant, the physico-theological proof. See KANT, supra note 9 , at 518-24. 
It remained unpersuasive because most legal thinkers truly did experience a sense of constraint, and this sense they ascribed to law.

Into the breach stepped Owen Fiss, who sought to construct an argument that would secure the objectivity of legal interpretation from the "nihilist" challenges. Fiss sought this objectivity by appealing to what he called "the interpretive community" and the "disciplining rules." 15 He inferred the existence of these constructs from the felt sense that adjudication $i s$ constrained and that legal texts such as the Constitution do have meaning. In other words, the experience of constraint in adjudication together with the feeling that the Constitution does mean something served as grounds for inferring the reality of the interpretive community and the disciplining rules.

What then are the interpretive community and the disciplining rules? The "interpetive community" is a term Fiss borrowed from Stanley Fish. ${ }^{16}$ But while the term is borrowed, its meaning is not. In contrast to Fish, who leaves the term capaciously vague and generously undetermined, Owen Fiss pins it down and fills it with content:

In law the interpretive community is a reality. It has authority to confer because membership does not depend on agreement. Judges do not belong to an interpretive community as a result of shared views about particular issues or interpretations, but belong by virtue of a commitment to uphold and advance the rule of law itself. ${ }^{17}$

As for "disciplining rules," Fiss provides a few concrete examples, such as consultation of author's intent and fidelity to precedent. ${ }^{18}$ In addition, he offers descriptions of the nature and content of these rules. If we assemble his statements, here is what the disciplining rules are and do:

1. They receive their authority from the interpretive community. ${ }^{19}$

2. They are the standards by which the correctness of interpretation is to be judged. ${ }^{20}$

3. They must be interpreted. ${ }^{21}$

4. They can be internalized. ${ }^{22}$

5. They can be objects of conscious self-reflection by judges. ${ }^{23}$

6. They are professional norms. ${ }^{24}$

15. See Owen M. Fiss, Objectivity and Interpretation, 34 Stan. L. REv. 739, 744-45 (1982).

I6. See Stanley Fish, Is There a Text in This Class? The Authority of INterpretive COMmUNities (I980).

17. Fiss, supra note 15, at 746.

18. See id. at 748,761 .

I9. See Owen M. Fiss, Conventionalism, 58 S. CAL. L. Rev. 177, 184 (1985).

20. See Fiss, supra note 15, at 744.

21. See Fiss, supra note 19, at 184.

22. See id. at 189.

23. See id. 
7. They constitute and define the interpretive community. ${ }^{25}$

8. They constrain legal interpretation. ${ }^{26}$

Notice that these little items are-like higher beings generallypossessed of rather wondrous qualities, particularly when considered in combination.

And, in a sense, this is not so surprising given that Fiss' account bears a resemblance to the fifth proof of God offered by Thomas Aquinas. In the fifth proof, Thomas Aquinas argues:

We see that things that lack consciousness such as bodies in nature function purposively. This is evident from the fact that they always, or nearly always, function in the same way, so as to achieve what is best. Therefore it is evident that they achieve their end, not by chance but by design. ${ }^{27}$

Aquinas here is talking about mindless nature-grass, sheep, and the like. It is striking, he notes, that this multiplicity of heterogeneous material nonetheless combines in a seemingly mindful way. The result is not chaos, but coherence. For Fiss, the corresponding move is to observe that the manifold of legal decisions seems to exhibit a certain degree of order and sense.

Aquinas continues, "But things that do not possess consciousness tend towards an end only because they are directed by a being that possesses consciousness and intelligence, in the same way that an arrow must be aimed by an archer."28 Correspondingly, on the plane of law, Fiss maintains that the apparent coherence of legal thought cannot be explained without positing the existence of an intelligent force constraining legal interpretation.

Meanwhile, Aquinas concludes, "Therefore there is an intelligent being who directs all things to their goal, and we say that this is God."29 And Fiss likewise concludes that there is some intelligent force constraining legal interpretation, and this we call the interpretive community and the disciplining rules.

Just as some have argued that there is not much difference between the argument from design and the cosmological proof, ${ }^{31}$ so it might be argued that there is not that much difference between Owen Fiss and Joseph Beale. They are both, after all, expositors of the same longstanding American jurisprudential tradition-one that yearns for a law

24. See id.

25. See id. at 184 .

26. See Fiss, supra note 15 , at 744.

27. Aquinas, supra note 10 , at 32 .

28. Id.

29. Id.

30. Kant, for instance, argues that the argument from design (what he calls "the physicotheological proof') collapses into the cosmological proof. See KANT, supra note 9, at 524. 
that is at once rational yet authoritative, objective yet flexible, stable yet protean, disciplined yet progressive (and so on).

The arguments of Beale and Fiss share another salient characteristic: both tend to confuse and conflate what is necessary in explanation with what is necessary in the world. As with Beale, there is with Fiss a problematic slippage from the epistemic to the ontological. Even if Fiss is right that the manifest sense of constraint that we experience in adjudication can only be explained by resort to something like the "interpretive community" and the "disciplining rules," he has succeeded at most in showing that this is so only as a matter of thought or reason.

We also observe in Fiss, as in Beale, a covert equivocation and equation at the end of his argument. Just as the intelligent being in Aquinas' proof turns out to be the fully fleshed out Judeo-Christian God, Fiss rather mysteriously equates the abstract interpretive community with our existing legal profession, and the mythic disciplining rules, with our own pedestrian canons of construction.

Now, it may seem that there is something odd in the suggestion that his "disciplining rules" are ontologically akin to the supernatural. But let us consider what we are buying into with these "disciplining rules." Let us ask, what kind of thing (if that is the right word) a "disciplining rule" might be? Fiss gives us the answer (and here I will rearrange some of the salient attributes of disciplining rules):

They are the standards by which the correctness of interpretation is to be judged; ${ }^{31}$ yet they constrain legal interpretation..$^{32}$

They receive their authority from the interpretive community ${ }^{33}$ yet they constitute and define the interpretive community. ${ }^{34}$

They can be objects of conscious self-reflection; ${ }^{35}$ yet once internalized, they direct interpretation. ${ }^{36}$

In short, like Beale's common law, the disciplining rules are at once object and subject. They are fixed, object-like entities and they are also mutable agencies of legal thought.

Here, one might ask: Is it conceivable that there are such things as disciplining rules? Just what kind of thing is it that would have such attributes? Or more pointedly still: Just what kind of thing is it that can

31. See Fiss, supra note 15 , at 744.

32. See id.

33. See Fiss, supra note 19 , at 184.

34. See id.

35. See id. at 189.

36. See id. 
sometimes be an object and sometimes be a subject and nonetheless retain its identity in its transubstantiation from the one to the other? Perhaps one can imagine responses to these questions that salvage "disciplining rules." Nonetheless, I do want to suggest that anyone who wants to argue in favor of the existence of such things as "disciplining rules" has to be prepared to advance a fairly magical metaphysic. But that is exactly the point: a magical metaphysic is precisely what should be expected from the jurisprudential use of a proof of God. Aquinas, of course, does own up to his metaphysics. Owen Fiss, by contrast, does not even begin to do the work: he simply offers an account of how his desirable $\mathrm{X}$ might be possible and presumes that this is sufficient.

Fiss' jurisprudential use of proofs of God is not unique. There are other examples where contemporary legal scholars have advanced arguments strikingly reminiscent of the proofs of God. Consider an example of the ontological proof.

\section{The Ontological Proof of God}

Recent questioning of the identity and ontological status of the liberal individual subject-what many of us call simply "the self"-has produced strong reactions in some quarters of the American legal academy. Various poststructuralist arguments have been received as threats to liquidate the autonomous individual subject. Indeed, poststructuralist arguments are received as assaults not just on the idea, but on the very sense of self. The poststructuralist troubling of the subject often enough produces the somewhat peeved response, "What do you mean, I don't exist?" It is as if the poststructuralist strategy raised the ad hominem argument to a new high-going beyond a mere attack on the self of the interlocutor to a flat-out denial of his existence altogether.

Not only do legal academics experience such poststructuralist arguments as psychologically upsetting, but they perceive that these arguments threaten the coherence and plausibility of normative argument about law. Indeed, the presumption of an autonomous, coherent, integrated self seems to be a necessary premise of just about every normative vision relevant to American law. One could reasonably think that the stakes are rather high. Some people find the stakes so high that they consider it sufficient to point out that the individual self must be real, because otherwise our normative systems would be incoherent. This is not a good argument. It is about as convincing as asserting that God cannot possibly be dead because, if he were, it would greatly complicate the life of the church.

A more sophisticated variant of this argument is offered by Margaret Jane Radin, Frank Michelman, and Jack Balkin. They have 
met the poststructuralist argnments with a move designed to establish the ontological integrity of the self. Responding to a series of challenges to the ontological integrity of the autonomous self, Radin and Michelman answer succinctly: "We cannot deny our own agency. (We cannot speak the sentence of denial except as speaking subjects, affirming by speaking the sentence what the sentence means to deny.)" ${ }^{\prime 37}$ The power of their argument (and notice that it has a certain familiar force) lies in the seemingly indubitable character of the presumption that the self exists. There can be no denial of the existence of the self, because, they argue, the very performance of the denial confirms the existence of the self.

Jack Balkin makes a similar point as he argues that the individual self is the necessary author of deconstruction. As he puts it,

Deconstruction, which seems to efface the self, ultimately depends upon what it de-emphasizes or denies-that is, the self. For only selves can put the self in question-there is quite literally no one else to do it. And only selves with preexisting commitments (political or otherwise) would engage in such a project. $^{38}$

This argument has an uncanny structural resemblance to the cogito ergo sum of Augustine ${ }^{39}$ and Descartes. In turn, the cogito has a certain structural resemblance to the ontological argument for the existence of God.

Consider first the cogito. Much of the force of the RadinMichelman-Balkin argument lies precisely in their invocation of the "I think therefore I am." The force of their argument-as in the cogito itself-lies in entangling those who disagree in an untenable performative contradiction. To deny the existence of the "I" is, in virtue of the very performance of the denial, to reassert the existence of the "I." The thinker performing the cogito is thus forced-on pain of an untenable performative contradiction-to accede to the existence of the "I." This logic of the cogito is present in the ontological proof as well. Indeed, like the cogito, the ontological proof uses the threat of an unten-

37. Margaret Jane Radin \& Frank Michelman, Pragmatist and Poststructuralist Critical Legal Practice, 139 U. PA. L. REv. 1019, 1058 (1991).

38. J.M. Balkin, Tradition, Betrayal, and the Politics of Deconstruction, 11 Cardozo L. Rev. 1613,1629 (1990).

39. As Augustine put the matter:

In the face of these truths, the quibbles of the skeptics lose their force. If they say; 'What if you are mistaken?'-well, if I am mistaken, I am. For, if one does not exist, he can by no means be mistaken. Therefore, I am, if I am mistaken. Because, therefore, 1 am, if I am mistaken, how can $I$ be mistaken that $I$ am, since it is certain that $I$ am, if $I$ am mistaken?

Saint Augustine, The City of God bk. 11, ch. 26, at 236 (Vernon J. Bourke ed., Gerald G. Walsh et al. trans., Image Books abr. ver. 1958) (emphasis omitted). 
able performative contradiction to extract the audience's assent to the existence of God. The argument goes very roughly as follows:

Existence is clearly involved in the idea of an infinitely perfect being (i.e. God).

To deny the existence of an infinitely perfect being is in effect to deny its perfection-for to exist is more perfect than not to exist.

\section{Therefore, God exists. ${ }^{40}$}

Now, this proof of God-insofar as it strives to prove the necessity of God's existence-is a failure. ${ }^{41}$ The problem is that either existence is smuggled into the first premise (in which case we have no argument, but merely an assertion) or the argument simply does not follow (for there is no contradiction in denying both the existence of God and his corresponding lack of perfection). Another way of putting the matter, one which relates more closely to my later claims, is to recognize that this proof too slips from the epistemic to the ontological. Even if existence is something that must be attributed to God as a conceptual matter, the necessity of this attribution remains confined to the epistemic realm and does not reach the ontological.

The cogito of Michelman, Radin, and Balkin exhibits this same shortfall. Perhaps there is no doubting the existence of the "I" that Michelman, Radin, and Balkin produce through the cogito. But again the existence established is far less than that desired. To rehearse the point: it's surely true that if "T" think, "I" am; and it's also true that if "I" deny my existence, "I" am again. But something far less than what we might think has been established here. The inexorable logic of the cogito establishes that whatever significance has been projected into the first "I" should come out in the second "I" as well. But what the Cartesian cogito does not, indeed cannot, validate is the significance that has been projected into the first "I." What remains undetermined, unthought, unsecured by the Cartesian cogito-as thinkers such as Nietzsche ${ }^{42}$ and Lyotard ${ }^{43}$ have pointed out-is the modality of existence

40. See St. Anselm, Monologion and Proslogion with the Replies of Gaunilo and ANSELM 99-100 (Thomas Williams trans., Hackett Publishing Co. 1996).

41. There are, of course, difficult issues concerning what constitutes "proof," and "failure," and the equally difficult question of "for whom?" For an interesting discussion more sympathetic to the theological perspective, see Mrchael Peterson et al., Reason and Religious Belief (1991).

42. As Nietzsche put it,

"There is thinking: therefore there is something that thinks": this is the upshot of all Descartes' argumentation. But that means positing as "true a priori" our belief in the concept of substance-that when there is thought there has to be something "that thinks" is simply a formulation of our grammatical custom that adds a doer to every deed. 
of this " $I$ " whose existence is so desired. At most, it is an " $I$ " in thought or language whose existence has been established. And of course Michelman, Radin, and Balkin (and perhaps you and I) had hopes for so much more.

What remains problematic about the proofs of God, and the arguments by Beale, Fiss, Radin, Michelman, and Balkin is that, in each case, the crucial utterances cannot escape the conditions of their enunciation, though they strive mightily to do so. They strive to use some assertion that must be true in thought as grounds for its being true as a matter of being. But this, short of artifice or faith, they cannot do.

\section{Magical Thinking}

Why and how do these secular legal thinkers reenact the various proofs of God in the context of jurisprudence? There is a puzzle here. If we wanted to be very hard on these legal thinkers (and I will for a couple of paragraphs), we would say that they are engaged in a form of magical thinking. This is a very harsh criticism, but it will be followed by rehabilitation.

The key aspect of "magical thinking" is the creation of metaphysical entities that make certain worldly events come out the way one desires. To engage in magical thinking, one simply posits a thought that will make things come out the way one desires and one then affirms that the thought is or refers to something that is ontologically real and ontologically effective. ${ }^{44}$ In magical thinking, epistemic necessities are transformed into ontological actualities. This is arguably what Beale, Fiss, Radin, Michelman, and Balkin are doing here. Indeed, it is difficult to escape the thought that these legal thinkers all yearn for the existence of a desirable $\mathrm{X}$, and that they are engaging in magical thinking to get it.

Friedrich Nietzsche, THE Will to Power 268 (Walter Kaufmann \& R. J. Hollingdale trans., Vintage Books I968) (190I). For Nietzsche, there is in the Cartesian cogito a kind of (illegitimate) slippage between the grammatical or indicative use of the word ' $T$ ' and the habitual tendency to accord substantive ontological content to the "I."

43. As Lyotard puts it, "[i]t is not the thinking or the reflective $I$ that withstands the test of universal [Cartesian] doubt, it is time and the phrase. It does not result from the phrase, I doubt, that I am, [but] merely that there has been a phrase." JEAN-FRANçors LYOTARD, THE DIFFEREND: Phrases IN Dispute 59 (Georges Van Den Abbeele trans., 1988) (citation omitted) (emphasis omitted and added). Lyotard also argues that the ambitions of cogito founder on the inability to establish the self-coincidence of the "1" over time:

It is through the name, an empty link, that $I$ at instant $t$ and $I$ at instant $t+1$ can be linked to each other and to Here I am (ostension). The possibility of reality, including the reality of the subject, is fixed in networks of names "before" reality shows itself . . . in an experience. Id. at 46 (emphasis omitted).

44. This is also the structure of what is called "fetishism" and "idolatry." For a sustained argument that constitutional (and, by implication, legal) interpretation partakes of such idolatry, see Steven D. Smith, Idolatry in Constitutional Interpretation, in CAMPOS ET AL., supra note 3, at 157. 
What is going on here? One possibility is that these thinkers all happen to be making the same conceptual error by sheer coincidence. This would be rather uninteresting. Moreover, it is unlikely: the legal thinkers here are leading figures. If they are engaged in a form of magical thinking, then very likely, so is their audience. That, of course, just accentuates the puzzle. How then does this kind of theological argumentation (with all its attendant problems) appeal to legal thinkers, many of whom understand themselves to be resolutely secular? One answer is:

\section{FAITH AND DESIRE}

American legal thinkers really do want their own desirable $X$ to exist, and so they cannot help but produce and reproduce a world of stabilized, transcendent signifiers in which the existence (a deep ontological existence) of their really desirable $\mathrm{X}$ is authorized and maintained. This is not strange. On the contrary, this is the standard-issue formalist dream: to use thought, reason, and language to stabilize the field so that the existence of the really desirable $X$ is authorized and maintained. This is what Beale does for "the common law," what Fiss does for "objectivity," what Radin, Michelman, and Balkin do for "the autonomous self,"45 and what any number of other legal thinkers do for their own versions of the desirable X.

It is this wish for the existence of the really desirable $\mathrm{X}$ that leads to formalism-to the formalization of the conditions of possibility for the really desirable $X$. Why are we prepared to accept and to reproduce such arguments? The answer is simple: it is only if some desirable $\mathrm{X}$ is possible that our own desirable $\mathrm{X}$ is conceivable. We are complicit in allowing and sustaining a form of argumentation in which the existence of some really desirable $\mathrm{X}$ might be possible. As legal thinkers, we are willing to knock somebody else's desirable X; however, what few, if any, of us are willing to do is to knock the rhetorical space and function of the desirable $X$ itself.

Much of the discourse of the legal academy is thus a contest of desires. The various desires are sublimated into more professionally respectable forms-namely, normative argument (the social face of desire). But it is the desire for the existence of the desirable $X$ that prompts legal thinkers to replicate the theological slippages from thought to being, from epistemics to ontology.

45. They (correctly) see this "self" as the linchpin of what they (incorrectly) consider to be the intellectually and politically respectable enterprise of normative legal argument. See Radin \& Michelman, supra note 37 , at 1057-58. 


\section{Law: Giving Formalism Its Due}

At this point, the anti-formalist urge is to do away with the error: "Let's stop viewing reason as constitutive of our world. Let's stop this constant slippage from the epistemic to the ontological. Let's follow Kant and simply use reason in its regulative capacity while forswearing its constitutive uses. ${ }^{46}$ From here on, we should understand that when legal propositions are uttered in rational form, the rational is simply an epistemic requirement. We talk in a rational way not because the social world is constituted according to principles of reason, but because we require reason in order to talk coherently."

This move would be possible, if it weren't for two things. First, the Kantian invitation to avoid using reason in a constitutive way may well be right, but it cannot be lived. The injunction arrives too late. As a cultural-intellectual matter, reason has already secreted its own objects and frames in language and practice. The categories of human social existence are already infused with what Kant called the transcendental illusions of reason: the imbrication of reason within the social world. Consequently, it is too late to step back and to proclaim that we will use reason only as a regulative, not a constitutive, ideal.

Second-and this is the rehabilitation-where American law is concerned, the slippage from the epistemic to the ontological is not a mistake. When Beale, Fiss, Radin, Michelman, and Balkin slip from the epistemic to the ontological, or from the general to the particular, they may be making a mistake as far as reason is concerned. They may also be engaged in a residually theological discourse. But even if this is true-and I argue that it is-they are not making a mistake as far as "doing law" is concerned. On the contrary, their argumentation is well within the tradition of American law. Law is constructed precisely through this kind of collective, projected objectification; get rid of the objectification, or, to put it another way, get rid of the illusion of objectification, and you get rid of law. ${ }^{47}$

46. Kant writes:

Reason is never in immediate relation to an object, but only to the understanding; and it is only through the understanding that it has its own [specific] empirical employment. It does not therefore, create concepts (of objects) but only orders them, and gives them that unity which they can have only if they be employed in their widest possible application, that is, .with a view to obtaining totality in the various series....

I accordingly maintain that transcendental ideas never allow of any constitutive employment. When regarded in that mistaken manner, and therefore as supplying concepts of certain objects, they are but pseudo-rational ....

KANT, supra note 9, at 532-33.

47. As Joseph Vining puts it:

A turn that is not made so long as one remains in legal discourse is that which is made at the beginning of much modern social science, the elimination of the entity in discourse by reducing or dissolving it " it," after the terms "him," "her," or "them" have been cast 
In one sense, the slippage from the epistemic to the ontological is a constitutive gesture of American law. The slippage from the epistemic to the ontological allows the law and its artifactual forms-doctrines, principles, policies, and so on-to be treated as objects in their own right. It is this slippage that enables legal thinkers to treat the law as an authoritative source that exists independently of the beliefs of the legal (or the wider) community. Not only does the slippage enable the law to be seen as authoritative, but it is also what enables the law to be frozen into a variety of fundamental identities (doctrines, principles, policies, and so on) that become amenable to what we call "legal analysis."

Beale, Fiss, Radin, Michelman, and Balkin are well within the tradition of American law in a second sense. The slippage between the epistemic and the ontological is one that is at the very heart of a crucial ambiguity of American law itself: law is at once a concrete social form embedded in institutional practices and an abstract conceptual representation of those institutions and practices. ${ }^{48}$ It is common in certain academic contexts to distinguish the two senses of law. But I would argue that the very idea of American law embodies and depends upon the confusion and conflation of the two. This conflation and confusion is crucial to the American idea of the rule of law, for it enables the widely shared faith in the otherwise odd belief that social institutions and practices are responsive to reason.

\section{The Illusion OF A Future}

For those who remain interested in "doing law," the popular alternative is to try to continue the legal conversation, minus the underlying metaphysic. This invitation issues from various anti-formalist quarters: postmodernists, neopragmatists, and so on. But short of dissonance or bad faith (both of which are certainly possible) there is no intellectually respectable way to do so. It is no more possible to continue doing law in an intellectually respectable way once the metaphysic is gone, than to continue worship once God is dead. Law is like Godhere. And once you say that God is just a bunch of conventions, he loses a great deal of his appeal. Correspondingly, worship comes to lack a certain seriousness. ${ }^{49}$ The same goes for law.

aside) into a point which is the focus of forces operating. The forces operating then become the real objects of interest, like the demons of primitive exclamation.

Such a tum is not made in legal discourse because, if it were made, the very object of inquiry would be lost.

Joseph Vining, From Newton's SLEEP 9 (1995).

48. It is, of course, many more things as well. For elaboration, see Pierre Schlag, Hiding the Ball, 71 N.Y.U. L. REv. 1681 (1996).

49. See Smith, supra note 44; see also Eric Blumenson, Mapping the Limits of Skepticism in Law and Morals, 74 TEx. L. REv. 523 (1996). 